\title{
The Effect of Discipline and Work Environment on Teacher Performance at SMK Negeri 2 Pondok Aren-South Tangerang
}

\author{
Dayat Hidayat \\ Pamulang University \\ Email: dayat_hidayat@unpam.ac.id
}

(Received: March 21-2020; revised: April 20-2020; published: June 31-2020)

\begin{abstract}
Teachers are the main key to improving the quality of education because an important requirement for the realization of quality education is if its implementation is carried out by professionally reliable educators. This study aims to determine the effect of discipline and work environment on teacher performance at SMK Negeri 2 Pondok Aren-South Tangerang. The method used is explanatory research with analysis techniques using statistical analysis with regression testing, correlation, determination, and hypothesis testing. The results of this study, the discipline has a significant effect on teacher performance by $44.7 \%$, the hypothesis test is obtained $t$ count $>t$ table or $(7,024>2,000)$. The work environment has a significant effect on teacher performance by $40.2 \%$, hypothesis testing is obtained $t$ count $>t$ table or $(6.398>2,000)$. Discipline and work environment simultaneously have a significant effect on teacher performance with the regression equation $\mathrm{Y}=10.637+0.386 \mathrm{X} 1+$ $0.365 \mathrm{X} 2$. The contribution of the effect was $54.7 \%$, the hypothesis test obtained $\mathrm{F}$ count $>\mathrm{F}$ table or $(36.188>2.760)$.
\end{abstract}

Keywords: Discipline: work environment: teacher performance

\section{INTRODUCTION}

The teacher is a teacher of science, teachers generally refer to professional educators with the main task of educating, teaching, guiding, directing, training, assessing and evaluating students (Darwis et al., 2019; Suprianto et al., 2018). Teacher performance can be seen from the work process or work results (Niswaty \& Arhas, 2019; Pope, 2019). A job always has work steps (procedures), work procedures always lead to increased work results following work demands. If a job is carried out according to the procedure, it will arrive at the desired work result. The benchmarks of performance are job demands that describe the work results to be achieved. How far a person can do the job then compared to the results achieved is called one's performance at that job (Al-Rahmi et al., 2018; Elacqua \& Marotta, 2020; Jacob et al., 2018; Pope, 2019)

A teacher who has high performance should have a positive attitude towards the work he is facing, such as discipline, likes to work seriously, maintains the quality of his work, is responsible, is highly dedicated, and so on. (Cuevas et al., 2018; Harris \& Sass, 2014; Suknaisith et al., 2014). Because of the importance of teacher performance factors in its role to improve the success of education, it is necessary to maintain and strive for highperformance teachers. What factors influence teacher performance improvement needs to be answered immediately so that the problem of improving the quality of education can be realized immediately. 
198 Jurnal Administrare: Jurnal Pemikiran Ilmiah dan Pendidikan Administrasi Perkantoran

Vol. 7, No. 1, January-June 2020, Pages 197-206

Teachers are the main key to improving the quality of education because an important requirement for the realization of quality education is if its implementation is carried out by educators whose professionalism can be relied on. (Sirait et al., 2019; Suknaisith et al., 2014). The world of education will not experience any change as long as the lecturers and teachers do not want to change, are not adaptive, and anticipatory to change (Kuriloff et al., 2019; Musfah, 2015).

In matters of independence and creativity, the management of education in schools is very dependent on the reliability of a school principal, where the principal has greater authority to make decisions related to school management policies compared to the education management system managed by the central government (Akib \& Saleh, 2015; Nasrullah et al., 2017; Suprapto \& Sunarsi, 2020). Meanwhile, in terms of openness and accountability of school management, the principal as the manager in managing and managing his school should pay attention to school management inputs. In carrying out teaching and learning activities the work environment is very supportive to provide teacher comfort, this affects teacher performance so that student learning achievement can decrease (Sunarsi, 2018; Sunarsi \& Asmalah, 2018).

The work environment is one of the important things in increasing the effectiveness of teacher work. Because the work environment and work environment can affect the physiology and psychology of teachers at work. As with discipline, discipline is closely related to fulfilling the smoothness of the learning and teaching process. Discipline is an ideal condition in supporting the implementation of tasks according to the rules to support work optimization. One of the requirements, so that discipline can be cultivated in the work environment, is a complete division of labor to the lowest employees or officers, so that everyone knows consciously what their duties are, how to do them, when work starts and is finished, what kind of work is required., and to whom is accountable for the results of the work. For this reason, discipline must be cultivated so that order and evasion will also grow. Without good discipline, do not expect the existence of an ideal leader or teacher as expected by society and organizations.

\section{METHOD}

This type of research used is associative, where the aim is to find out how to find a connection between. A population is a group of objects that are determined through certain criteria which will be categorized into the object to be studied. The population in the study amounted to 63 respondents at SMK Negeri 2 Pondok Aren-South Tangerang. According to (Sugiyono, 2017), the population is the number of generalized areas consisting of objects or subjects that have the qualities and characteristics set by the researcher, and conclusions are drawn.

The sample in this study amounted to 63 respondents. According to (Sugiyono, 2017), the sample is the number and characteristics possessed by the population. While (Arikunto, 2019) argue that the sample is part or representative of the population studied. So that the sampling technique in this study is a saturated sample, where all members of the population are used as samples. In analyzing the data used instrument test, classical assumption test, regression, coefficient of determination, and hypothesis testing. 


\section{RESULT AND DISCUSSION}

\section{The Effect of Discipline on Teacher Performance}

Correlation coefficient analysis is intended to determine the level of strength of the relationship between the independent variables and the dependent variable either partially or simultaneously. The test results are as follows:

Table 1.

The Results of Discipline Correlation Coefficient Testing on Teacher Performance Correlations $^{\mathbf{b}}$

\begin{tabular}{llr|r}
\hline & & $\begin{array}{c}\text { Discipline } \\
(\mathrm{X} 1)\end{array}$ & \multicolumn{1}{c}{$\begin{array}{c}\text { Teacher } \\
\text { Performance (Y) }\end{array}$} \\
\hline Discipline (X1) & Pearson Correlation & 1 & $.669^{* *}$ \\
\cline { 2 - 4 } Teacher Performance (Y) & Sig. (2-tailed) & & .000 \\
\cline { 2 - 4 } & Pearson Correlation & $.669^{* *}$ & 1 \\
\cline { 2 - 4 } & Sig. (2-tailed) & .000 & \\
\hline
\end{tabular}

**. Correlation is significant at the 0.01 level (2-tailed).

b. Listwise $\mathrm{N}=63$

Based on the test results obtained a correlation value of 0.669 means that discipline has a strong relationship with teacher performance.

Analysis of the coefficient of determination is intended to determine the percentage of influence of the independent variable on the dependent variable either partially or simultaneously. The test results are as follows:

Table 2.

Results of Discipline Determination Coefficient Testing on Teacher Performance

\begin{tabular}{|c|c|c|c|c|}
\hline \multicolumn{5}{|c|}{ Model Summary } \\
\hline Model & $\mathrm{R}$ & R Square & $\begin{array}{c}\text { Adjusted R } \\
\text { Square }\end{array}$ & $\begin{array}{c}\text { Std. Error of the } \\
\text { Estimate }\end{array}$ \\
\hline 1 & $.669^{\mathrm{a}}$ & .447 & .438 & 2.717 \\
\hline
\end{tabular}

a. Predictors: (Constant), Discipline (X1)

Based on the test results, it was found that the value of determination was 0.447 , meaning that discipline had an influence of $44.7 \%$ on teacher performance.

Hypothesis testing with the t-test is used to determine which partial hypothesis is accepted. The first hypothesis: there is a significant influence between discipline on teacher performance. 
200 Jurnal Administrare: Jurnal Pemikiran Ilmiah dan Pendidikan Administrasi Perkantoran Vol. 7, No. 1, January-June 2020, Pages 197-206

Table 3.

Discipline Hypothesis Test Results on Teacher Performance Coefficients $^{\mathbf{a}}$

\begin{tabular}{|c|c|c|c|c|c|c|}
\hline \multirow{2}{*}{\multicolumn{2}{|c|}{ Model }} & \multicolumn{2}{|c|}{$\begin{array}{l}\text { Unstandardized } \\
\text { Coefficients }\end{array}$} & \multirow{2}{*}{$\begin{array}{c}\text { Standardized } \\
\text { Coefficients } \\
\text { Beta }\end{array}$} & \multirow[b]{2}{*}{$\mathrm{t}$} & \multirow[b]{2}{*}{ Sig. } \\
\hline & & B & Std. Error & & & \\
\hline & (Constant) & 17.885 & 3.064 & & 5.838 & .000 \\
\hline & Discipline (X1) & .563 & .080 & .669 & 7.024 & .000 \\
\hline
\end{tabular}

a. Dependent Variable: Teacher Performance (Y)

Based on the test results in the table above, the value of $t$ count> $t$ table or $(7,024>$ 2,000 ) is obtained, thus the first hypothesis proposed that there is a significant influence between discipline on teacher performance is accepted.

\section{Effect of Work Environment on Teacher Performance}

Correlation coefficient analysis is intended to determine the level of strength of the relationship between the independent variables and the dependent variable either partially or simultaneously. The test results are as follows:

Table 4.

Results of Testing the Correlation Coefficient of the Work Environment on Teacher Performance

\section{Correlations $^{\mathrm{b}}$}

\begin{tabular}{llr|r}
\hline & & \multicolumn{1}{c|}{$\begin{array}{c}\text { Work } \\
\text { environment (X2) }\end{array}$} & $\begin{array}{c}\text { Teacher } \\
\text { Performance (Y) }\end{array}$ \\
\hline Work environment (X2) & Pearson Correlation & 1 & $.634^{* *}$ \\
\cline { 2 - 4 } & Sig. (2-tailed) & & .000 \\
\hline Teacher Performance (Y) & Pearson Correlation & $.634^{* *}$ & 1 \\
\cline { 2 - 5 } & Sig. (2-tailed) & .000 & \\
\hline
\end{tabular}

**. Correlation is significant at the 0.01 level (2-tailed).

b. Listwise $\mathrm{N}=86$

Based on the test results obtained a correlation value of 0.634 means that the work environment has a strong relationship with teacher performance.

Analysis of the coefficient of determination is intended to determine the percentage of influence of the independent variable on the dependent variable either partially or simultaneously. The test results are as follows: 
Table 5.

Results of Testing the Coefficient of Determination of the Work Environment on Teacher Performance

\begin{tabular}{|c|c|c|c|c|}
\hline \multicolumn{5}{|c|}{ Model Summary } \\
\hline Model & $\mathrm{R}$ & R Square & $\begin{array}{l}\text { Adjusted R } \\
\text { Square }\end{array}$ & $\begin{array}{l}\text { Std. Error of the } \\
\text { Estimate }\end{array}$ \\
\hline 1 & $.634^{a}$ & .402 & .392 & 2.827 \\
\hline
\end{tabular}

a. Predictors: (Constant), Work environment (X2)

Based on the test results, it was obtained a determination value of 0.402 , meaning that the work environment had an influence contribution of $40.2 \%$ on teacher performance.

Hypothesis testing with the t-test is used to determine which partial hypothesis is accepted. The first hypothesis: there is a significant influence between the work environment on teacher performance

Table 6.

Hypothesis Test Results Working Environment on Teacher Performance

\begin{tabular}{|c|c|c|c|c|c|}
\hline \multirow[b]{3}{*}{ Model } & \multicolumn{2}{|c|}{ Coefficients $^{\mathrm{a}}$} & \multirow{3}{*}{$\begin{array}{l}\text { Standardized } \\
\text { Coefficients } \\
\text { Beta }\end{array}$} & \multirow[b]{3}{*}{$\mathrm{t}$} & \multirow[b]{3}{*}{ Sig. } \\
\hline & \multicolumn{2}{|c|}{$\begin{array}{l}\text { Unstandardized } \\
\text { Coefficients }\end{array}$} & & & \\
\hline & $\mathrm{B}$ & Std. Error & & & \\
\hline $1 \quad$ (Constant) & 15.914 & 3.668 & & 4.339 & .000 \\
\hline Work environment (X2) & 610 & .095 & .634 & 6.398 & .000 \\
\hline
\end{tabular}

a. Dependent Variable: Teacher Performance (Y)

Based on the test results in the table above, the $t$ value> $t$ table or $(6.398>2,000)$ is obtained, thus the second hypothesis that is proposed that there is a significant effect between the work environment on teacher performance is accepted,

\section{The Effect of Discipline and Work Environment on Teacher Performance}

Correlation coefficient analysis is intended to determine the level of the strength of the relationship between the independent variable and the dependent variable either partially or simultaneously. The test results are as follows:

Table 7.

Results of Testing the Discipline and Work Environment Correlation Coefficient Simultaneously to Teacher Performance

\begin{tabular}{|c|c|c|c|c|}
\hline \multicolumn{5}{|c|}{ Model Summary ${ }^{b}$} \\
\hline Model & $\mathrm{R}$ & R Square & $\begin{array}{l}\text { Adjusted R } \\
\text { Square }\end{array}$ & $\begin{array}{l}\text { Std. Error of the } \\
\text { Estimate }\end{array}$ \\
\hline 1 & $.739^{a}$ & .547 & .532 & 2.480 \\
\hline
\end{tabular}

a. Predictors: (Constant), Work environment (X2), Discipline (X1)

b. Dependent Variable: Teacher Performance (Y) 
202 Jurnal Administrare: Jurnal Pemikiran Ilmiah dan Pendidikan Administrasi Perkantoran Vol. 7, No. 1, January-June 2020, Pages 197-206

Based on the test results obtained a correlation value of 0.739 means that the discipline and work environment simultaneously have a strong relationship with teacher performance.

Analysis of the coefficient of determination is intended to determine the percentage of influence of the independent variable on the dependent variable either partially or simultaneously. The test results are as follows:

Table 8.

Results of Discipline Determination Coefficient Testing and Work Environment on Teacher Performance

Model Summary

\begin{tabular}{|c|c|c|c|c|}
\hline Model & $\mathrm{R}$ & R Square & $\begin{array}{l}\text { Adjusted R } \\
\text { Square }\end{array}$ & $\begin{array}{l}\text { Std. Error of the } \\
\text { Estimate }\end{array}$ \\
\hline 1 & $.739^{\mathrm{a}}$ & .547 & .532 & 2.480 \\
\hline
\end{tabular}

a. Predictors: (Constant), Work environment (X2), Discipline (X1)

Based on the test results, it was found that the value of determination was 0.547 , meaning that the discipline and work environment simultaneously contributed $54.7 \%$ to the teacher's performance, while the remaining $44.1 \%$ was influenced by other factors.

Hypothesis testing with the $\mathrm{F}$ test is used to determine which simultaneous hypothesis is accepted. The third hypothesis There is a significant influence between discipline and work environment on teacher performance.

Table 9.

Discipline and Work Environment Hypothesis Test Results on Teacher Performance ANOVA $^{\mathrm{a}}$

\begin{tabular}{llr|r|r|r|c}
\hline Model & & Sum of Squares & \multicolumn{1}{c}{ df } & Mean Square & \multicolumn{1}{c}{ F } & \multicolumn{1}{c}{ Sig. } \\
\hline 1 & Regression & 445.277 & 2 & 222.638 & 36.188 & $.000^{\mathrm{b}}$ \\
\cline { 2 - 7 } & Residual & 369.136 & 60 & 6.152 & & \\
\cline { 2 - 7 } & Total & 814.413 & 62 & & & \\
\hline
\end{tabular}

Based on the test results in the table above, the value of $F$ count> $F$ table or $(36,188>$ 2,760 ) is obtained, thus the third hypothesis proposed that there is a significant influence between discipline and work environment on teacher performance is accepted.

\section{DISCUSSION}

\section{The Effect of Discipline on Teacher Performance}

From the analysis, it was found that the discipline variable had a significant effect on teacher performance with a correlation value of 0.669 meaning that the two variables had a strong relationship with an influential contribution of $44.7 \%$. Hypothesis testing obtained $t$ value $>t$ table or $(7,024>2,000)$. Thus the first hypothesis proposed that there is a significant effect between discipline on teacher performance is accepted 


\section{Effect of Work Environment on Teacher Performance}

From the analysis, it was found that the work environment variable had a significant effect on teacher performance with a correlation value of 0.634 , meaning that the two variables had a strong relationship with an influential contribution of $40.2 \%$. Hypothesis testing obtained $t$ value $>t$ table or $(6.398>2,000)$. Thus, the second hypothesis proposed that there is a significant effect between the work environment and teacher performance is accepted.

\section{The Effect of Discipline and Work Environment on Teacher Performance}

From the analysis, it was found that the discipline and work environment variables had a significant effect on teacher performance by obtaining the regression equation $\mathrm{Y}=10.637$ $+0.386 \mathrm{X} 1+0.365 \mathrm{X} 2$, the correlation value was 0.739 , meaning that the two variables had a strong relationship with an influential contribution of $54.7 \%$ while the rest was equal to $44.1 \%$ is influenced by other factors. Hypothesis testing obtained the value of $\mathrm{F}$ count> $\mathrm{F}$ table or $(36.188>2.760)$. Thus, the third hypothesis proposed that there is a significant effect between discipline and work environment on teacher performance is accepted.

\section{CONCLUSION}

Based on the results of the research and discussion that has been described, it can be concluded that the results of this study are 1) Discipline has a significant effect on teacher performance, a correlation value of 0.669 , or strong with a contribution of influence of $44.7 \%$. Hypothesis test obtained $t$ value $>t$ table or $(7,024>2,000)$. Thus there is a significant influence between discipline on teacher performance at SMK Negeri 2 Pondok Aren-South Tangerang; 2) The work environment has a significant effect on teacher performance with a correlation value of 0.634 or strong with an influence contribution of $40.2 \%$. Hypothesis test obtained $t$ value $>t$ table or $(6.398>2,000)$. Thus there is a significant influence between the work environment on teacher performance at SMK Negeri 2 Pondok Aren-South Tangerang; 3) Discipline and work environment have a significant effect on teacher performance with a correlation value of 0.739 or strong with an influence contribution of $54.7 \%$ while the remaining $44.1 \%$ is influenced by other factors. Hypothesis testing obtained the value of $\mathrm{F}$ count> F table or $(36.188>2.760)$. Thus there is a significant influence between discipline and work environment simultaneously on teacher performance at SMK Negeri 2 Pondok Aren-Tangerang Selatan.

\section{REFERENCES}


204 Jurnal Administrare: Jurnal Pemikiran Ilmiah dan Pendidikan Administrasi Perkantoran Vol. 7, No. 1, January-June 2020, Pages 197-206 